\title{
Studies of Trace Metals in the Leaves of Phyllanthus emblica (L)
}

\author{
JAYA GUPTA and AMIT GUPTA \\ Department of Chemistry, Agra College, Agra, India. \\ *Corresponding author E-mail: jayagupta6250@gmail.com \\ http://dx.doi.org/10.13005/ojc/290435 \\ (Received: October 10, 2013; Accepted: December 02, 2013)

\begin{abstract}
The leaves of Phyllanthus emblica were digested with $\mathrm{HNO}_{3}$ and $\mathrm{HClO}_{4}(4: 1)$ and the contents of trace elements such as $\mathrm{Zn}, \mathrm{Fe}, \mathrm{Ni}, \mathrm{Mn}, \mathrm{K}, \mathrm{Ca}, \mathrm{Mg}, \mathrm{Co}, \mathrm{Cr}, \mathrm{Cu}, \mathrm{Cd}, \mathrm{Pb}$, and $\mathrm{As}$ were determined by atomic absorption spectroscopy. The experimental results confirmed the presence of $\mathrm{Ca}, \mathrm{Fe}, \mathrm{Zn}$, $\mathrm{Mg}, \mathrm{K}, \mathrm{Co}$ and $\mathrm{Mn}$ which is beneficial to the human body is within the limit but concentration of $\mathrm{Ni}$ is high. The heavy trace element which are harmful to human body i.e., $\mathrm{Cd}$, As, within the limit but concentration $\mathrm{Cu}, \mathrm{Cr}, \mathrm{Pb}$ is high.
\end{abstract}

Key words: Phyllanthus emblica, Atomic absorption spectroscopy, Trace elements.

\section{INTRODUCTION}

Phyllanthus emblica Linn. (Euphorbiaceae) known as Indian gooseberry is a very richest source of vitamin $\mathrm{C}^{1}$ found in abundant amount in deciduous forest of Madhya Pradesh. It is common all over tropical and sub-tropical India. It is known as amalaka in Sanskrit, amla in Hindi, olay in Punjabi , aamla in Gujarati,nellikkai in Tamil. It has antiviral, antibacterial ${ }^{2}$, anti-proliferative, antiplatelet ${ }^{3-5}$ anti -HIV-1, hypolipidamic properties. It is used as antioxidant, aphrodisiac, as chelating agent, in constipitation, dental problems, diabetes ${ }^{6}$ , diarrhoea, diuretic fevers gonorrhea, hair growth, headache ${ }^{7}$, inflammation mouth ulcers, respiratory problems, skin whitening etc. The plant leaves have the antineutrophilic activity. It reduces blood cholesterol, blood glucose as well as triglyceride levels $^{8-9}$

Heavy metal distribution in plants is of interest because of their essential or toxic nature. For example,zinc ,iron, cobalt, chromium ,copper and manganese are essential, while cadmium, lead, nickel are toxic at certain levels. In past few years research of trace element distribution in medicinal plants ${ }^{10-13}$ becomes important. Trace elements are the essential for human health and they prevent several diseases. The atomic absorption spectroscopy ${ }^{14-15}$ is an important method for detection of trace elements. 


\section{EXPERIMENTAL}

Leaves of Phyllanthus emblica are picked from Agra and Mathura. For fifteen days, the samples were air dried under shade. Then powdered with the help of warming blender, $2.5 \mathrm{gm}$ ground dried plant leaves were place in a $250 \mathrm{ml}$ conical flask, $2.5 \mathrm{ml}$ concentrated $\mathrm{HNO}_{3}$ was added slowly with constant shaking. The mixture was heated on a hot plate until the production of brown fumes ceases. The content of beaker was cooled and $10 \mathrm{ml}$ of $70 \% \mathrm{HClO}_{4}$ was added. It was heated again very gently until the solution turns colorless and allowed to evaporating to a small volume. Now cooled and added double distilled water and was filtered into a $100 \mathrm{ml}$ flask using Whatmann filter paper and volume was diluted with double distilled water. The total concentrations of $\mathrm{Zn}, \mathrm{Fe}, \mathrm{Ni}, \mathrm{Mn}, \mathrm{K}, \mathrm{Ca}, \mathrm{Mg}, \mathrm{Co}, \mathrm{Cr}, \mathrm{Cu}, \mathrm{Cd}, \mathrm{Pb}$, As etc. were analyzed by atomic absorption spectroscopy (Model: Perkin Elmer A Analyst 100)

\section{RESULTS AND DISCUSSION}

The concentration of cadmium in leaf is $0.005 \mathrm{ppm}$ of Agra but it is absent in sample of Mathura. The permissible limit set by WHO is 0.2 to $0.81 \mathrm{ppm}$. Thus in Phyllanthus emblica concentration of cadmium is within limit. Cadmium is a non essential trace element. Cadmium biochemically replaces zinc and causes high blood pressure. Cd damages kidney and liver $^{16}$. Cadmium causes a disease known as Itai-Itai.
The concentration of copper is $4.625 \mathrm{ppm}$ in leaf sample of Agra and 6.458ppm in leaf sample of Mathura. Copper is required for some essential enzymes such as super oxide dismustase, cytochrome oxidase, lysyl oxidase, etc. Excess of copper results in dermatitis, metallic taste in the mouth, hair and skin decoloration etc. Copper ${ }^{17}$ play role in some neurological conditions like Alzheimer's disease, Wilson's disease. In edible plants permissible limit set by FAO/WHO in 1984 was 3.00 ppm. Thus in Phyllanthus emblica copper is more than permissible limit. Sample of Mathura contains more copper in comparison to sample of Agra.

The concentration of lead in leaf sample of Agra is $22.215 \mathrm{ppm}$ and $25.438 \mathrm{ppm}$ in leaf sample of Mathura. Lead has no beneficial effects in humans. Lead exposure produces harmful effects 16-17. Lead poisoning results in anemia, headache, brain damage, chronic nephritis of kidneys. The permissible limit set by WHO is 0.1 to $10 \mathrm{ppm}$. Thus concentration of lead in Phyllanthus emblica is high.

The concentration of arsenic in leaf sample of Agra is $0.041 \mathrm{ppm}$ and $0.031 \mathrm{ppm}$ in leaf sample of Mathura. In medicinal plants concentration of arsenic recommended is less than $1.0 \mathrm{ppm}^{20}$. So it is within limit. Excess of arsenic causes metabolic disorder, dermatitis, lung cancer, cardiovascular and neurological effects.

Table 1: Essential trace elements

\begin{tabular}{|c|c|c|c|}
\hline \multicolumn{2}{|c|}{$\begin{array}{l}\text { Phyllanthus emblica } \\
\text { (leafs) of Agra }\end{array}$} & \multicolumn{2}{|c|}{$\begin{array}{l}\text { Phyllanthus emblica } \\
\text { (leafs) of Mathura }\end{array}$} \\
\hline Element & Mean & Element & Mean \\
\hline $\mathrm{Zn}$ & 12.325 ppm & $\mathrm{Zn}$ & 9.428 ppm \\
\hline $\mathrm{Fe}$ & $54.965 \mathrm{ppm}$ & $\mathrm{Fe}$ & $56.983 \mathrm{ppm}$ \\
\hline $\mathrm{Ni}$ & $4.532 \mathrm{ppm}$ & $\mathrm{Ni}$ & 3.862 ppm \\
\hline $\mathrm{Mn}$ & $48.157 \mathrm{ppm}$ & $\mathrm{Mn}$ & $43.024 \mathrm{ppm}$ \\
\hline $\mathrm{K}$ & 6.028 ppm & $\mathrm{K}$ & 5.035 ppm \\
\hline $\mathrm{Ca}$ & $42.842 \mathrm{ppm}$ & $\mathrm{Ca}$ & $40.627 \mathrm{ppm}$ \\
\hline $\mathrm{Mg}$ & $38.774 \mathrm{ppm}$ & $\mathrm{Mg}$ & 29.374 ppm \\
\hline Co & $0.066 \mathrm{ppm}$ & Co & $0.083 \mathrm{ppm}$ \\
\hline
\end{tabular}


Table 2: harmful heavy metals

\begin{tabular}{llll}
\hline \multicolumn{2}{c}{$\begin{array}{c}\text { Phyllanthus emblica } \\
\text { (leafs) of Agra }\end{array}$} & \multicolumn{2}{c}{$\begin{array}{c}\text { Phyllanthus emblica } \\
\text { (leafs) of Mathura }\end{array}$} \\
Element & Mean & Element & Mean \\
\hline $\mathrm{Cu}$ & $4.625 \mathrm{ppm}$ & $\mathrm{Cu}$ & $6.458 \mathrm{ppm}$ \\
$\mathrm{Cr}$ & $11.415 \mathrm{ppm}$ & $\mathrm{Cr}$ & $12.232 \mathrm{ppm}$ \\
$\mathrm{Cd}$ & $0.005 \mathrm{ppm}$ & $\mathrm{Cd}$ & $\mathrm{ND}$ \\
$\mathrm{Pb}$ & $22.215 \mathrm{ppm}$ & $\mathrm{Pb}$ & $25.438 \mathrm{ppm}$ \\
$\mathrm{As}$ & $0.041 \mathrm{ppm}$ & $\mathrm{As}$ & $0.031 \mathrm{ppm}$ \\
\hline
\end{tabular}

In Phyllanthus emblica concentration of $\mathrm{Ni}$ in leaf sample of Agra is 4.532ppm and 3.862ppm in leaf sample of Mathura. In 1984 FAO/ WHO set permissible limit for $\mathrm{Ni}$ is $1.683 \mathrm{ppm}$. No limit yet been given by $\mathrm{WHO}$ in 2005 for $\mathrm{Ni}$ in medicinal plants. Ni plays an important role in the production of insulin. Nickel compounds bind a variety of enzymes, including hepatic microsomal enzymes, as well as enzymes that catalyze carbohydrate metabolism and transport of ions across membranes. Nickel was thought to be essential to plants and some domestic animals ${ }^{21}$ but not considered to be a metal of biological importance .But after discovery of urease (nickel enzyme ${ }^{22}$ ) it is consider as an element of biological importance. Lungs are adversely affected by $\mathrm{Ni}$ and it is identified as a suspected carcinogen. Nickel can cause a skin disorder known as nickel eczema ${ }^{23}$.Thus concentration nickel in Phyllanthus emblica is high.

In leaf sample of Agra concentration of iron is $54.965 p p m$ and 56.983ppm in sample of Mathura. For $\mathrm{Fe}$ in medicinal plants limits not yet been established by WHO in 2005. For the formation of hemoglobin iron is necessary. For the transfer of oxygen and electron transfer $\mathrm{Fe}$ is required in human body ${ }^{24}$.Iron deficiency is the most prevalent nutritional deficiency in humans ${ }^{25}$.

Concentration of $\mathrm{Cr}$ in leaf of sample of Agra is $11.415 p p m$ and $12.232 p p m$ in leaf sample of Mathura. Trivalent chromium is necessary for the normal metabolism of cholesterol, fat and glucose ${ }^{26}$. Chromium is one of the known environmental toxic pollutants in the world. Tanneries, sewage sludge application, steel industries and fly ashes are main sources of chromium pollution. Chromium is recognized as pulmonary carcinogen by U.S. Toxicology Programme. No limit yet been established by WHO (2005) for Cr. In medicinal plants, Canada set 2 ppm permissible limit in raw medicinal plant material. Thus concentration of $\mathrm{Cr}$ is very high.

Concentration of $\mathrm{K}$ in leaf of Phyllanthus emblica is 6.028ppm in the sample of Agra and $5.035 \mathrm{ppm}$ in the sample of Mathura. $\mathrm{K}$ is essential to all organisms with the possible exception of blue green algae. It is a major cation and is important in nerve action. The requirement of $\mathrm{K}$ is estimated to be 0.2 to $0.6 \%$ of the dry weight of the animal's .Potassium reduces blood pressure. It is moderately toxic to mammals when injected intravenously. Thus potassium is present within limit in Phyllanthus emblica.

The concentration of zinc in the leaf of Phyllanthus emblica is $12.325 p p m$ in the sample of Agra and 9.428ppm in the sample of Mathura. The permissible limit set by FAO/WHO (1984) in edible plants was $27.4 \mathrm{ppm}$. Several biological roles of zinc have been reported and over 200 proteins and enzymes contain zinc. Zn produces important role in DNA synthesis, brain development, steroidogenesis ${ }^{27}$ bone formation, wound healing ${ }^{28}$. Thus concentration of zinc is within limit.

The concentration of calcium in the sample of Agra is 42.842ppm and 40.627ppm in the sample of Mathura. Calcium is essential for all organisms, used in cell walls, bones. Calcium helps in transporting of long chain fatty acids which helps in preventing high blood pressure, heart diseases and some other cardiovascular diseases.

The concentration of magnesium in the sample of Agra is $38.774 \mathrm{ppm}$ and in the sample of Mathura is 29.374ppm.Magnesium works with 


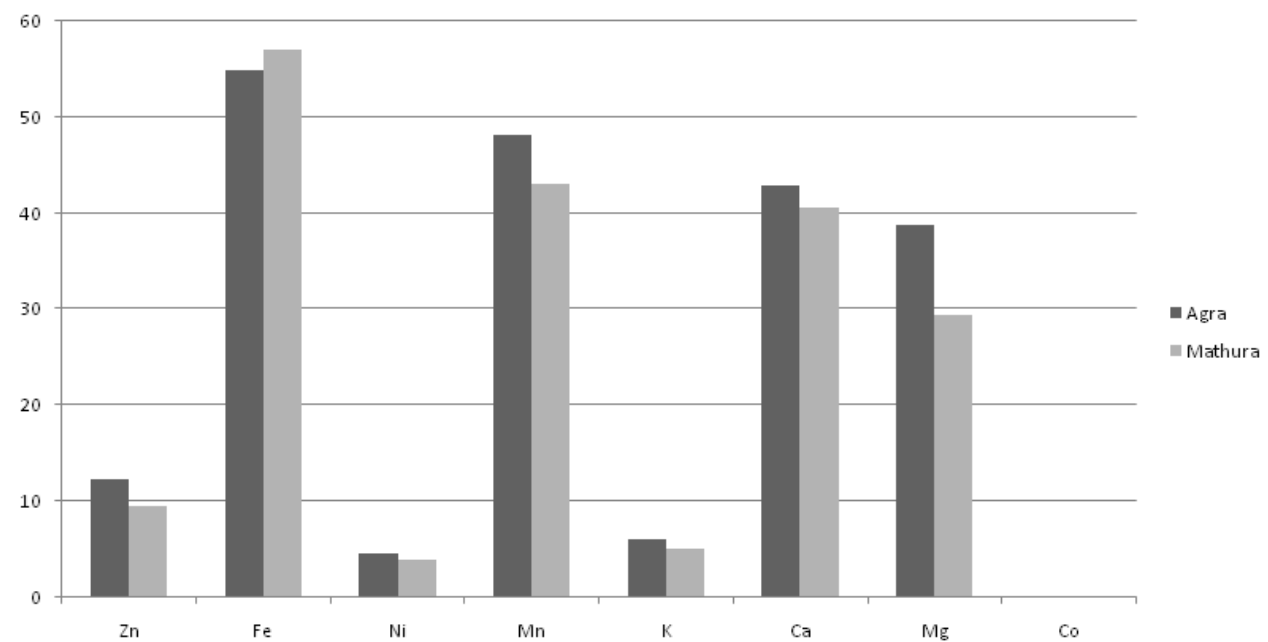

Fig. 1: Comparative study of essential trace elements in Agra and Mathura

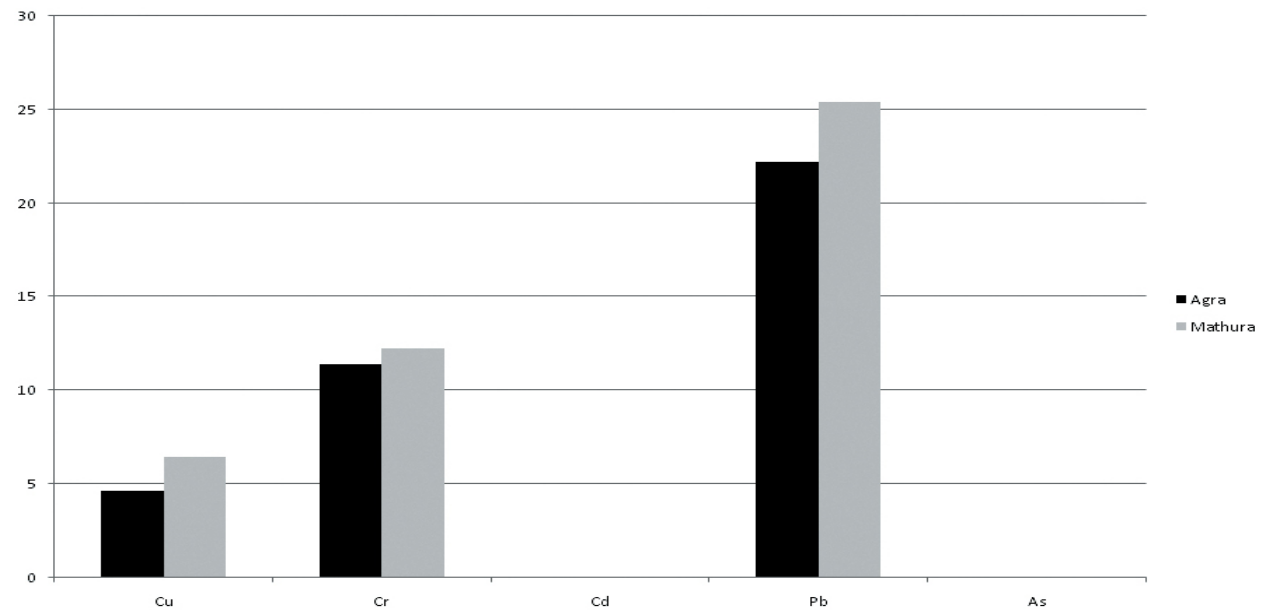

Fig. 2: Comparative study of harmful heavy metals in Agra and Mathura

calcium to help transmitting nerve impulse in the brain. Magnesium has calming effect and works on the nervous system of those peoples, suffering from depression. In blood its quantity is $2-4 \mathrm{mg} / 100 \mathrm{ml}$.

The concentration of cobalt in the sample of Agra is $0.066 \mathrm{ppm}$ and in the sample of Mathura is $0.083 \mathrm{ppm}$. There is no established criteria for cobalt in medicinal plants. In turkey $0.14 \mathrm{ppm}$ to $0.48 \mathrm{ppm}$ concentration of cobalt was determined in seven herbs $^{29}$. Cobalt activates many metalloenzymes. Cobalt is found in Vitamin- $\mathrm{B}_{12}$ and plays an important role in the synthesis of hemoglobin and DNA.
Thus on the basis of above results, it is found that Phyllanthus emblica contain useful trace elements $\mathrm{Ca}, \mathrm{Fe}, \mathrm{Zn}, \mathrm{Mg}, \mathrm{K}, \mathrm{Mn}$, Co with in limit but $\mathrm{Ni}$ is high. Harmful heavy metals $\mathrm{As}, \mathrm{Cd}$, are also with in limit but concentration of $\mathrm{Cu}, \mathrm{Cr}, \mathrm{Pb}$ is higher.

\section{ACKNOWLEDGEMENTS}

We are very grateful to University Grants Commission, New Delhi, India for their financial assistance (Grant No.F.15-39/12 (SA-II)). We are also very thankful to Dr.A.K.Gupta, Head of the Department of Chemistry and Dr.M.K.Rawat, Principal Agra College, Agra for their support. 


\section{REFERENCES}

1. Tarwadi,K., and Agte, V., Int J Food Sci Nutr, 58(5): 341 (2007).

2. Khopde, S.M., Priyadarshni, K.I.,Guha,S.N., Satav,J.G., Vankatesan,P., and Rao, M.N.A., Biosci.Biotechnol.Biochem, 64: 503 (2000).

3. Raghu,H.S., and Ravindara,P., International Journal of Pharmaceutical Studies and Research, 1: 30 (2010)

4. Chaterjee,A.,Chattopadhyay,S., and Bandyopadhyay S.K., Evidince Based Complementary and Alternative Medicine, p1-13 (2011).

5. Charoenteeraboon, J. Ngamkitidechakul, C., Soonthornchareonnon, N., Jaijoy,K., and Sireeratawong,S., J.Sci. Technol, 32(6): 599 (2010).

6. Rao ,T.P., Sakaguchi ,N., Juneja,L.R., Wada,E., and Yokozawa,T.J., Med Food 8(3): 362-368 (2005).

7. Perry,L.M., Medicinal Plants of East and Southeast Asia, MIT Press. Cambridge, p149150 (1980).

8. Jacob,A., Pandey,M., Kapoor,S., and Saroja,R., Eur .J Clin Nutr, 42 (11), 939 (1988).

9. Qureshi,S.A., Asad,W., and Sultana,V., Pakistan Journal of Nutrition 8(2) 125-128 (2009).

10. Wang,Y., Wang,S.J., and Wang,L.X., China Pharmacol. J., 39: 877 (2004).

11. Zhang S.B., and Guo,Y.S., Chin. J.Health Lab. Technol., 46: 15 (2005).

12. Jaya Gupta, Orient. J. Chem., 29(3): 10891097 (2013)

13. J. P. Noudogbessi and D. C. K. Sohounhloue., Orient. J. Chem., 29(1): 59-67 (2013)

14. Liu,C.H.,Wang,C.H., and Liu,Z.P., Spectrosc.
Spect. Anal., 28: 686 (2008).

15. Liang, B.A., and Zhang, F.J., Spectrosc. Spect. Anal., 27: 813, (2007).

16. Neil, P.O., Minor Element and Environmental Problems, Environmental Chemistry, $2^{\text {nd }} \mathrm{Ed}$. 96 (1993).

17. Onyamborko,N.V., Benemariya,H., Robberecht,H., and Deelstra,H., Food Chem Biotech., 45: 21 (1990)

18. Chukhlovin, A.B., Tokalov, S.V., Yagunov, A.S., Westendorf, J., Reincke,H., and Karbe,L., Sci.Total Environ., 281: 153 (2001)

19. Hsu, P.C., and Guo, Y.L., Toxicology, 180: 33 (2002)

20. WHO, Monographs on Selected Medicinal Plants, Vol.1 World Health Organization, Geneva (1999).

21. Wang,K.,Nickel Trace Elements in Life Science, Chinese Measurement Press,Perking, China, pp. 275-280 (1991).

22. Zerner,B.,Bioorg.Chem.,19: 116 (1991).

23. Kristiansen,J., Christensen,J.M., Henriksen,T., Nielsen,N,H., and Menne,T., Anal,Chim.Acta, 403: 265 (2000).

24. Kaya.I., and Incekara ,N., J. Turkish Weed Sci., 3: 56 (2000).

25. Reddy,M.B., Chidambaram,M.V., Bates,G.W., Iron Transport in Microbes, Plants and AnimalsVCH, NewYork, (1987).

26. Barceloux,G.D., Clin Taxicol. 37, 239, (1999)

27. Apagar J.,Ann.Rev.Nutr.,5,43 (1985)

28. Lima-Hermes,M.,Pereira B., and Bechara, E.J.H., Xenobiotica, 21: 1085 (1991).

29. Basgel, S., Erdemoglu,S.B., Turkey.Sci.Total Env. 359: 82-89 (2006). 